\title{
Flavonoids, total phenolics and antioxidant capacity: comparison between commercial green tea preparations
}

\author{
Flavonoides, fenólicos totais e capacidade antioxidante: comparação entre bebidas comerciais à base de chá verde
}

\author{
Débora Harumi KODAMA ${ }^{1}$, Any Elisa de Souza Schmidt GONÇALVES ${ }^{1}$, \\ Franco Maria LAJOLO ${ }^{1}$, Maria Inés GENOVESE ${ }^{1 *}$
}

\begin{abstract}
The potential health benefits attributed to green tea and its catechins such as antioxidant effects, cancer chemoprevention, and weight loss have led to a huge increase of green tea products in the food market. The objectives of this work were to analyze and compare these products in terms of phenolic contents and in vitro antioxidant capacity including tea bags, dehydrated leaves, and ready-to-drink preparations after standardization of the infusion preparation procedure. Total phenolics content in 1 cup of the different teas varied from 90 to $341 \mathrm{mg}$ of catechin equivalents, and the highest and the lowest values were both those of the ready-to-drink products. Infusions prepared from tea bags had contents varying from 96 to $201 \mathrm{mg} .200 \mathrm{~mL}^{-1}$, and there were no significant differences among batches. The DPPH radical scavenging and the Oxygen Radical Absorbing Capacities (ORAC) varied largely among the different tea preparations, from 23 to $131 \mathrm{mmoles}$ of Trolox Equivalents (TE). $200 \mathrm{~mL}^{-1}$ (DPPH), and from 1.2 to 5.1 mmoles of TE. $200 \mathrm{~mL}^{-1}$ (ORAC), but again there were no differences among infusions or ready-to-drink commercial preparations. However, the antioxidant capacity of ready-to-drink products was partially due to the presence of other non-phenolic compounds such as ascorbic acid.
\end{abstract}

Keywords: antioxidant capacity; catechins; total phenolics; green tea.

\section{Resumo}

Os benefícios de saúde atribuídos ao chá verde e suas catequinas têm levado a um grande aumento de produtos comerciais à base de chá verde no mercado. Os objetivos deste trabalho foram analisar e comparar estes produtos em relação ao conteúdo de fenólicos totais e capacidade antioxidante in vitro, incluindo produtos na forma de sachês, folhas desidratadas e bebidas prontas. O conteúdo de fenólicos totais em $200 \mathrm{~mL}$ (1 xícara) dos diferentes chás variou de 90 a $341 \mathrm{mg}$ equivalentes de catequina, e o maior e o menor valor foram apresentados pelas bebidas prontas. As infusões preparadas a partir dos sachês tiveram conteúdos variando de 96 a $201 \mathrm{mg} .200 \mathrm{~mL}^{-1}$, e não foram encontradas diferenças significativas entre os lotes. Nos ensaios de sequestro do radical DPPH e ORAC (Oxygen Radical Absorbing Capacity), houve ampla variação dos resultados entre as diferentes preparações de chás, de 23 a 131 mmoles equivalentes de Trolox (ET).200 mL ${ }^{-1}$ (DPPH), e de 1,2 a 5,1 mmoles ET.200 mL (ORAC), e novamente não houve diferenças entre as infusões e/ou bebidas comerciais prontas. Entretanto, a capacidade antioxidante das bebidas prontas para consumo é parcialmente devido à presença de outros compostos não fenólicos como o ácido ascórbico.

Palavras-chave: capacidade antioxidante; catequinas; fenólicos totais; chá verde.

\section{Introduction}

Tea (Camellia sinensis L.) is the second most consumed beverage in the world, and it was used for centuries by old civilizations due to its medicinal properties besides its sensorial attributes. Consumption of green tea is especially popular in Asian countries, and the association with anti-inflammatory, anti-proliferative and anti-atherosclerotic activities has led to the inclusion of green tea extracts in dietetic supplements, nutraceuticals, and functional foods. Approximately 76 to $78 \%$ of the tea produced and consumed in the world is black tea, $20-22 \%$ is green tea, and $<2 \%$ is oolong tea (WU; WEI, 2002). The consumption of green tea by the Brazilian population has recently increased, mainly due to the propagation of its potential health benefits, including enhancing weight loss.
Green tea is characterized by its high flavonoid content, mainly catechins (20-30\% of the dry weight). Catechins are colorless, water-soluble flavan-3-ols and contribute with the bitter taste and astringency of the green tea infusion. The major catechins are (-)-epigallocatechin gallate (EGCG), (-)-epigallocatechin (ECG), (-)-epicatechin gallate (ECG), $(-)$-gallocatechin (GC), and (+)-catechin (C). EGCG is regarded as the most important tea catechin because of its high content, corresponding to approximately $40 \%$ of the total (WANG; PROVAN; HELLIWEL, 2000). Such as other classes of flavonoids, EGCG has antioxidant activities based on free radicals scavenging and metal chelation. In addition, polyphenols of tea seem to have other important biological

Recebido para publicação em 12/2/2009

Aceito para publicação em 20/6/2009 (004064)

Laboratório de Química, Bioquímica e Biologia Molecular de Alimentos, Departamento de Alimentos e Nutrição Experimental, Faculdade de Ciências Farmacêuticas,

Universidade de São Paulo - USP, Av. Prof. Lineu Prestes, n. 580, Bloco 14, CEP 05508-900, São Paulo - SP, Brasil, E-mail: genovese@usp.br

${ }^{*}$ A quem a correspondência deve ser enviada 
activities such as cancer chemoprevention and protection against UV-induced damage to the skin (NAGLE; FERREIRA; ZHOU, 2006).

According to this, the objectives of this study were to evaluate and compare the content of total phenolics and catechins and the in vitro antioxidant capacity of the commercial green tea preparations available in the Brazilian market including tea bags, tea leaves, and ready-to-drink products.

\section{Experimental}

\subsection{Samples}

The samples were obtained from supermarkets in the city of São Paulo, in the year of 2008, consisting of two batches of each commercial brand and three samples of each batch. The green tea bags analyzed and the respective weights of each individual bag, according to the producers, were as follows: Kitano (1.8 g), Real Multiervas (1.5 g), Leão (1.6 g), Api-Chá (1.5 g), Dr. Oetker $(1.7 \mathrm{~g})$, and Yamamotoyama $(2.0 \mathrm{~g})$. The traditional types of Green tea leaves analyzed were: Chá Verde de Primeira Colheita (Senchá), Yamamotoyama (200 g), and Banchá Yamamotoyama (200 g). Ready-to-drink products: Green Tea Leão sabor limão $(330 \mathrm{~mL})$, Feel Good sabor limão $(330 \mathrm{~mL})$, Feel Good com soja (1 L), and Chá Verde sabor Limão Lipton (340 mL).

\section{Infusion preparation}

Distilled water $(200 \mathrm{~mL})$ was firstly heated at $97^{\circ} \mathrm{C}$, to which the tea bags (triplicate) were immersed for 5 minutes. During the first 30 seconds, the bags were submersed 10 times. After 2.5 minutes, the procedure was repeated, and at the end of the 5 minutes, the tea bags were carefully removed and the tea was immediately conditioned in a glass jar. The jar was covered to avoid water evaporation and after cooling, the volume of the infusion was adjusted again to $200 \mathrm{~mL}$. Infusions using tea leaves were prepared similarly using $1.5 \mathrm{~g}$ (also in triplicate) of each of the samples, which were removed through filtration after 5 minutes.

\subsection{Chemicals}

The HPLC standards (+)-catechin, (-)-gallocatechin, (-)-epicatechin, (-)-epicatechin gallate, (-)-epigallocatechin and (-)-epigallocatechin gallate, the 2,2-diphenyl-1-picrylhydrazyl $\left(\mathrm{DPPH}^{\circ}\right)$, fluorescein, and the Folin-Ciocalteu reagents were purchased from Sigma Co (St. Louis, MO). The hydroxy2,5,7,8-tetramethylchroman-2-carboxylic acid (Trolox) was purchased from Aldrich (Milwaukee, WI) and the 2,2'-azobis (2-amidinopropano) dihidrocloreto (AAPH) was purchased from Wako Chemicals Inc. (Richmond, EUA). All chemicals and solvents used were analytical or HPLC grade when necessary.

\subsection{Total phenolics content}

The determination of the total phenolics content was performed using the Folin-Ciocalteu reagent, according to Singleton, Orthofer and Lamuela-Raventos (1999), with some modifications. A $0.25 \mathrm{~mL}$ aliquot of the infusions obtained above or of the ready-to-drink teas, appropriately diluted, was mixed with $0.25 \mathrm{~mL}$ of the Folin-Ciocalteu reagent and $2 \mathrm{~mL}$ of distillated water. After 3 minutes at room temperature, $0.25 \mathrm{~mL}$ of a saturated sodium carbonate $\left(\mathrm{Na}_{2} \mathrm{CO}_{3}\right)$ solution was added and the mixture placed at $37^{\circ} \mathrm{C}$ in a water bath for 30 minutes. The absorbance was measured at $750 \mathrm{~nm}$ using a model Ultrospec $2000 \mathrm{UV} /$ visible spectrophotometer (Amersham Biosciences, Cambridge, U.K.). Catechin was used as the reference standard, and the results were expressed as $\mathrm{mg}$ of catechin equivalents. $200 \mathrm{~mL}^{-1}$.

\subsection{Flavonoids analysis}

An aliquot of $25 \mathrm{~mL}$ of the teas studied was added to a $1 \mathrm{~g}$ polyamide SC6 column (Macherey-Nagel Gmbh and Co, Düren, Germany) preconditioned with methanol $(20 \mathrm{~mL})$ and water $(60 \mathrm{~mL})$. The column was washed with water $(20 \mathrm{~mL})$ and further eluted with methanol $(40 \mathrm{~mL})$ and with methanol/ammonia (99.5:0.5) (ARABBI; GENOVESE; LAJOLO, 2004). Those fractions were evaporated to dryness under pressure at $40^{\circ} \mathrm{C}$, redissolved in HPLC grade methanol $(1 \mathrm{~mL})$, and filtered through $0.22 \mu \mathrm{m}$ PTFE (polytetrafluoroethylene) filters (Millipore Ltd., Bedford, MA). The identification and quantification of flavonoids was achieved using analytical reversed-phase HPLC in a Hewlett-Packard 1100 system with autosampler and quaternary pump coupled to a diode array detector. The column used was $250 \times 4.6 \mathrm{~mm}$, i.d., $5 \mu$, Prodigy ODS3 reversed phase silica (Phenomenex Ltd., Torrance, CA) and elution solvents were: A, water:tetrahydrofuran:trifluoro acetic acid (98:2:0.1) and B, acetonitrile. The solvent gradient was the same one used by Genovese et al. (2008), except for the initial \% B of 5\%. The samples were injected in duplicate. The calibration was performed by injecting the standards three times at five different concentrations. The results were expressed as $\mathrm{mg} .200 \mathrm{~mL}^{-1}$ of tea.

\subsection{In vitro antioxidant capacity}

\section{$D P P H$ radical-scavenging capacity}

The antioxidant capacity was determined by the $\mathrm{DPPH}^{\bullet}$ (2,2-diphenyl-1-picrylhydrazyl) radical-scavenging method according to Brand-Willians, Cuvelier and Berset (1995), with some modifications (DUARTE-ALMEIDA et al., 2006). A $50 \mu \mathrm{L}$ aliquot of the sample previously diluted and $250 \mu \mathrm{L}$ of $0.5 \mathrm{mM}$ methanolic DPPH were mixed, and after 20 minutes the absorbance was measured at $517 \mathrm{~nm}$ using a Microplate Spectrophotometer (Benchmark Plus, BioRad, Hercules, CA). The control consisted of a methanolic solution of Trolox (6-hydroxy-2,5,7,8-tetramethylchroman-2-carboxylic acid) at different concentrations. The antioxidant capacity was expressed as mmoles Trolox equivalents (TE). $200 \mathrm{~mL}^{-1}$ of tea.

\section{Oxygen Radical Absorbing Capacity (ORAC) assay}

The assay was based on the procedure described by Dávalos, Gómez-Cordovés and Bartolomé (2004), adapted to individual cuvettes. The reaction was carried out in $75 \mathrm{mM}$ phosphate buffer ( $\mathrm{pH} 7.4$ ), and the final reaction mixture was $2 \mathrm{~mL}$. The samples $(0.2 \mathrm{~mL})$ and fluorescein $(1.2 \mathrm{~mL} ; 70 \mathrm{nM}$, final concentration) 
solutions were preincubated for 15 minutes at $37^{\circ} \mathrm{C}$; then $2,2^{\prime}$ azobis-(2-amidinopropane) dihydrochloride (AAPH) solution (600 $\mu \mathrm{L} ; 12 \mathrm{mM}$, final concentration) was added rapidly, and the fluorescence $(485 / 525)$ was recorded every minute for 80 minutes in a Hitachi F-3010 fluorescence spectrophotometer (Tokyo, Japan). A blank (FL + AAPH) using methanol instead of the antioxidant solution and a calibration curve using Trolox (0.4-4.8 $\mu \mathrm{M}$, final concentration) as antioxidant were also carried out in each assay (HUANG; OU; PRIOR, 2005; OU; HAMPSCHWOODILL; PRIOR, 2001). The results were expressed as mmoles Trolox Equivalents (TE). $200 \mathrm{~mL}^{-1}$ of tea.

\subsection{Statistical analysis}

All analyses were run in triplicate, and the results were expressed as mean \pm Standard Deviation (SD). Statistical analysis was performed using the Statistic software package version 5.0 (StatSoft, Inc., Tulsa, OK). The differences between means were first analyzed by ANOVA test and then Least Significant Difference (LSD) test $(\mathrm{p}<0.05)$. The data were subjected to Pearson correlations.

\section{Results and discussion}

The preparation of the infusions is one of the most important steps in the analysis of the different commercial brands of green tea considering that the efficiency of the phenolic extraction will depend on it (PRIOR; CAO, 1999). In order to avoid interferences resulting from the producers' different instructions, the analysis procedure was standardized for all the products, regardless of the brand, followed by a careful attention to details, considering meticulous details such as the removal of the tea bag from the infusion. Six different brands of green tea bags were analyzed and compared to four readyto-drink green tea based products and three infusions prepared from traditional dry green tea leaves, using almost the same amount contained in one bag.

The total phenolics content in $200 \mathrm{~mL}$ (1 cup) of the different teas varied from 90 to $341 \mathrm{mg}$ of catechin equivalents, and the highest and the lowest values were both those of the ready-to-drink products. Infusions prepared from tea bags had contents varying from 96 to $201 \mathrm{mg} .200 \mathrm{~mL}^{-1}$, and there were no significant differences among batches, except for the readyto-drink sample with the highest phenolic content (278 and $341 \mathrm{mg} .200 \mathrm{~mL}^{-1}$ ). Infusions prepared from tea leaves presented contents similar to those prepared from tea bags, from 114 to $168 \mathrm{mg} .200 \mathrm{~mL}^{-1}$ (Figure 1).

According to Prior and Cao (1999), since dry tea is not consumed directly, brewing conditions may influence the final antioxidant capacity of the tea as consumed, and in the first brewed cup ( $1.95 \mathrm{~g}$ to $150 \mathrm{~mL}$ ), approximately $84 \%$ of the total antioxidant activity was solubilized within the first 5 minutes of brewing. An additional 13\% of the antioxidant activity was extracted into the second glass of $150 \mathrm{~mL}$ with an additional 5 minutes of brewing.

In this work, after rigid control of brewing conditions, it was observed that the DPPH radical scavenging capacities varied almost six times among the different tea preparations, from 23 (Bancha tea leaves) to 131 (Leão tea bag) mmoles of TE. $200 \mathrm{~mL}^{-1}$, and they remained constant for different batches of the same product. Among categories of teas, i.e. bags, leaves and ready-to-drink products, no tendencies could be observed with values from 44 to 131 for teas prepared from bags, 23 to 95 from leaves, and 28 to 109 for ready-to-drink products (Figure 2).

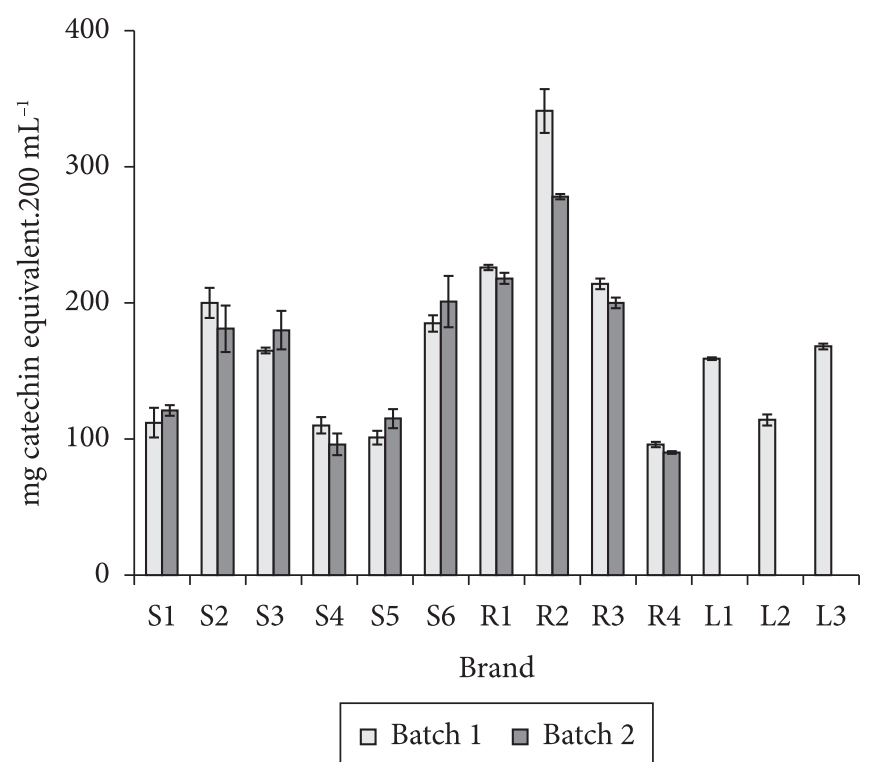

Figure 1. Total phenolic content (Folin-Ciocalteu reducing capacity) of different green tea preparations (mg catechin equivalents. $200 \mathrm{~mL}^{-1}$ ). Teas prepared from sachets (teabags): S1, Kitano (1.8 g), S2, Real Multiervas (1.5 g), S3, Leão (1.6 g), S4, Api-Chá (1.5 g), S5, Dr. Oetker (1.7 g) and S6, Yamamotoyama (2.0 g). Ready-to-drink products: R1, Feel Good, R2, Leão, R3, Feel Good with soy, and R4, Lipton. Infusions prepared from green tea leaves (1.5 g): L1, Senchá, L2, Banchá, L3, Yamamotoyama.

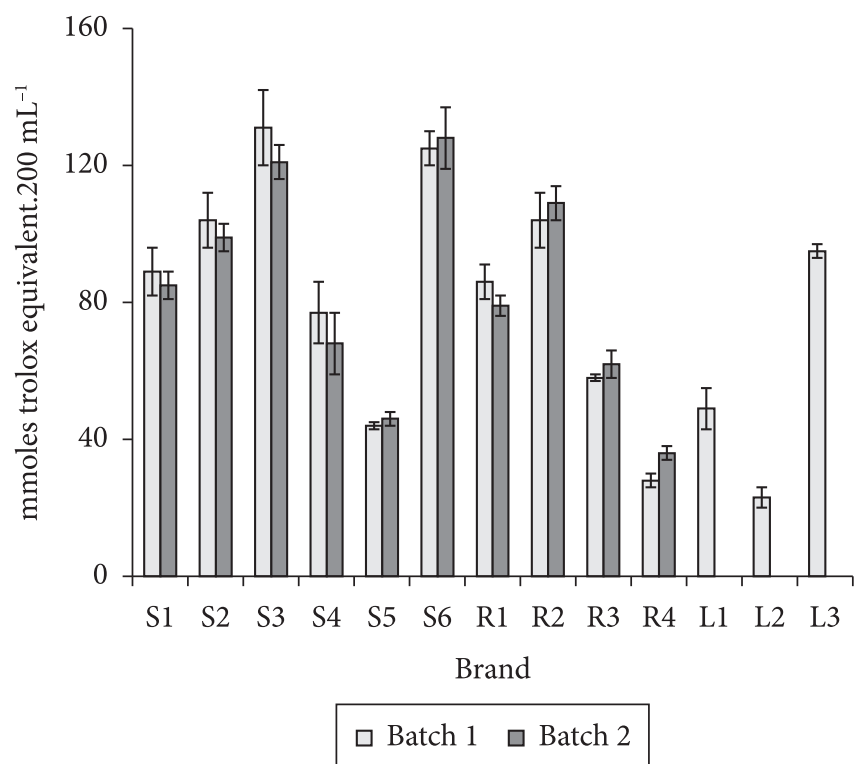

Figure 2. DPPH Radical Scavenging Activity of different green tea preparations (mmoles Trolox equivalents. $200 \mathrm{~mL}^{-1}$ ). Teas prepared from sachets (teabags): S1, Kitano (1.8 g), S2, Real Multiervas (1.5 g), S3, Leão (1.6 g), S4, Api-Chá (1.5 g), S5, Dr. Oetker (1.7 g) and S6, Yamamotoyama (2.0 g). Ready-to-drink products: R1, Feel Good, R2, Leão, R3, Feel Good with soy, and R4, Lipton. Infusions prepared from green tea leaves (1.5 g): L1, Senchá, L2, Banchá, L3, Yamamotoyama. 
Similarly, the Oxygen Radical Absorbing Capacity (ORAC) also varied largely among preparations, from 1.2 (Bancha tea leaves) to 5.1 (Feel Good Soy) mmoles of TE. $200 \mathrm{~mL}^{-1}$, and again no differences were observed among preparations with values from 2 to 4.9 for teas prepared from bags, 1.8 to 5.1 from leaves, and 1.2 to 4.4 for ready-to-drink products (Figure 3). The highest values among ready-to-drink products were observed for the preparation containing soy extract instead of the Leão sample (Figure 3).

These differences can be explained based on the different mechanisms involved in the two methods of antioxidant capacity determination, which are a hydrogen atom transfer reaction (ORAC) and an electron transfer (DPPH) (HUANG; OU; PRIOR, 2005). In this way, it is expected that samples with different compositions such as green teas with and without soy phenolics behave differently in these two in vitro models.

Also, when comparing tea infusions and ready-to-drink products, it is important to take into consideration the presence of additives (antioxidants, conservatives, and acidifiers) in ready-to drink products such as citric acid, besides added sugar and sweeteners. The ascorbic acid added to these products is also an antioxidant and depending on the concentration, it can also react with the Folin reagent used to quantify total phenolics, as it was previously observed by Duarte-Almeida et al. (2006) and Hassimotto, Genovese and Lajolo (2005).

Hence, ready-to-drink products were submitted to solid phase extraction in polyamide columns in order to separate phenolic compounds from other kinds of antioxidants artificially added. In Table 1, it can be observed that after the clean-up procedure significant reductions on the phenolic contents and antioxidant capacity were observed, probably resulting from the ascorbic acid removal. For instance, the phenolic content of the Feel Good product dropped from an average value of 222 to $89 \mathrm{mg}$ of catechin equivalents per cup (from 310 to 70 for Leão,

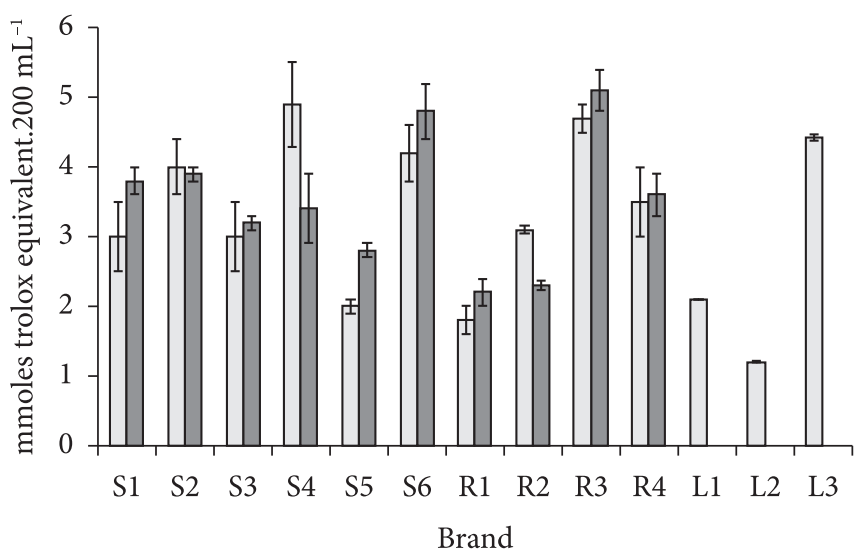

Batch $1 \square$ Batch 2

Figure 3. Oxygen Radical Absorbance Capacity (ORAC) of different green tea preparations (mmoles Trolox equivalents. $200 \mathrm{~mL}^{-1}$ ). Teas prepared from sachets (teabags): S1, Kitano (1.8 g), S2, Real Multiervas (1.5 g), S3, Leão (1.6 g), S4, Api-Chá (1.5 g), S5, Dr. Oetker (1.7 g) and S6, Yamamotoyama (2.0 g). Ready-to-drink products: R1, Feel Good, R2, Leão, R3, Feel Good with soy, and R4, Lipton. Infusions prepared from green tea leaves (1.5 g): L1, Senchá, L2, Banchá, L3, Yamamotoyama. and from 207 to 80 for Feel Good with soy). The DPPH radical scavenging activity decreased to one-half its original value for all the samples, and the ORAC dropped from 4.9 to 2.7 for Feel Good soy and from 2.7 to $1.0 \mathrm{mmol}$ trolox. $200 \mathrm{~mL}^{-1}$. As can be seen, the phenolics from soy seem to have an important contribution to the ORAC of this sample since it presented the highest value among these preparations.

According to Prior and Cao (1999), at the dilutions obtained after the first brewing, the tea prepared from tea bags would contain approximately $8.3 \mu \mathrm{mol}$ of Trolox equivalents per $\mathrm{mL}$ as consumed, or $1.7 \mathrm{mmol} \mathrm{TE} .200 \mathrm{~mL}^{-1}$, similar to the values observed in this study. Expressing our results in terms of weight of tea (bag or leaves), the ORAC values ranged from 707 to $3034 \mu \mathrm{mol} \mathrm{TE} . \mathrm{g}^{-1}$, also in the same range of values reported by Henning et al. (2003), of 728 to 1686 TE. ${ }^{-1}$ for regular teas and 507 to $845 \mu \mathrm{mol} \mathrm{TE} . \mathrm{g}^{-1}$ for decaffeinated teas, and by Prior

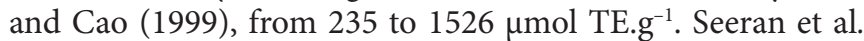
(2006) reported ORAC values of green tea dietary supplements, from 166 to $13690 \mu \mathrm{mol} \mathrm{TE} . \mathrm{g}^{-1}$ tablet or capsule. These results show that the consumption of tea on a regular basis can make a significant contribution to the total daily antioxidant capacity intake.

Considering all the different green tea preparations, it was not found a good correlation between total phenolic content determined by the Folin-Ciocalteu and DPPH radical scavenging capacity $(r=0.58)$. However, analyzing samples separately, a good correlation was found for teabags $(\mathrm{r}=0.81)$ and ready-to-drink samples $(\mathrm{r}=0.97)$. On the other hand, no correlation was found among these and the ORAC values (Table 2).

Health-promoting properties are intimately related to the activity of the natural antioxidants present in fruits and vegetables since, potentially, those components may reduce the level of oxidative stress decreasing the incidence of pathological dysfunction in the organism. Epidemiological studies suggest that a high intake of food rich in natural antioxidants increase the antioxidant capacity of the plasma and reduces the risk of cancer, heart diseases, and stroke. These properties are attributed to a variety of constituents including vitamins, minerals, and

Table 1. In vitro antioxidant capacity of commercial green tea beverages after solid-phase extraction.

\begin{tabular}{lccc}
\hline Ready-to-drink & Total phenolics (TP) & DPPH & ORAC \\
\hline beverage & $\left(\mathrm{mg}\right.$ catechin.200 $\left.\mathrm{mL}^{-1}\right)$ & $\left(\mathrm{mmol}\right.$ Trolox.200 $\left.\mathrm{mL}^{-1}\right)$ \\
\hline Feel good & $89 \pm 2$ & $47 \pm 1$ & $1.9 \pm 0.2$ \\
Green tea leão & $70 \pm 8$ & $46 \pm 4$ & $1.0 \pm 0.1$ \\
Feel good soy & $80 \pm 1$ & $38 \pm 3$ & $2.7 \pm 0.1$ \\
\hline
\end{tabular}

Table 2. Pearson's correlation coefficient among the antioxidant capacities of green tea preparations.

\begin{tabular}{lccc}
\hline & TP $\times$ DPPH & TP $\times$ ORAC & DPPH $\times$ ORAC \\
\hline Teabag & 0.81 & 0.44 & 0.52 \\
Teabag + dry leaves & 0.68 & 0.45 & 0.78 \\
Ready-to-drink & 0.97 & -0.33 & -0.53 \\
All samples & 0.58 & 0.06 & 0.42 \\
\hline
\end{tabular}


several phytochemicals, among which flavonoids stand out by the innumerous biological activities demonstrated in vitro and in animal models. In order to estimate the in vivo beneficial potential of a sample and/or compound, two or more different in vitro methods are recommended to evaluate the antioxidant activity since different mechanisms may be involved. A number of radical scavenging capacity assays have been widely used for the rapid screening and evaluation of antioxidants using peroxyl, hydroxyl ( $\left.\mathrm{HO}^{*}\right)$, cation ABTS $\left(\mathrm{ABTS}^{++}\right)$, peroxide anion $\left(\mathrm{O}_{2}^{-*}\right)$, and 2,2-diphenyl-1-picryhydrazyl (DPPH') radicals. The stable $\mathrm{DPPH}^{*}$ and the chemically generated $\mathrm{ABTS}^{\bullet+}$ are still highly utilized in antioxidant research due to their simple reaction systems, which involve only the direct reaction between the radical and the antioxidants and have no other interference such as enzyme inhibition or the presence of multiple radicals, although they are not as physiologically relevant as the ORAC, which determines the peroxyl radical scavenging capacities. The $\mathrm{DPPH}^{*}$ scavenging capacity assay is considered to be a valid and easy colorimetric method for antioxidant property evaluation, and the ORAC method has been indicated as the more physiologically significant (CHENG; MOORE; YU, 2006; DÁVALOS; GÔMEZ-CORDOVÉS; BARTOLOMÉ, 2004).

With regard to the flavonoid composition of the different green tea preparations, the major tea catechins identified were epigallocatechin (EGC), epicatechin gallate (ECG), and epigallocatechin gallate (EGCG), in the infusions prepared using tea bags or dry leaves (Figure 4). Besides those, gallocatechin (GC) was also found in ready-to-drink products (Figure 5). EGCG and EGC were the predominant compounds in all the samples. According to Seeran et al. (2006), EGCG makes up about $40 \%$ of the total catechin content, and it is widely accepted as the major antioxidant ingredient in green tea. Quercetin derivatives, the main representatives of the flavonol subclass of the flavonoid group, were also identified in all the preparations in amounts ranging from 2.6 to $8.6 \mathrm{mg}$ of aglycone. $200 \mathrm{~mL}^{-1}$. Fruits, vegetables and beverages such as tea and red wine are especially rich sources of these compounds (HERTOG; HOLLMAM; KATAN, 1993; NIJVELDT et al., 2001). Lower contents were previously reported for two Brazilian brands of green tea and a brand of "ban-chá", from 0.7 to $1.0 \mathrm{mg}$ of quercetin. $200 \mathrm{~mL}^{-1}$, accompanied by very low levels of kaempferol (0.3 to 0.6$)$ and myricetin $\left(0.2\right.$ to $\left.0.5 \mathrm{mg} .200 \mathrm{~mL}^{-1}\right)$ (MATSUBARA; RODRIGUEZ-AMAYA, 2006).

Among the different preparations, the lowest concentrations of catechins were those of Bancha, which seems to be in accordance with the lowest antioxidant capacity. As expected, although there was a high variability in catechin levels, there was no difference among the preparations made from bags or leaves and ready-to-drink beverages. The highest total flavonoid content was $197 \mathrm{mg} .200 \mathrm{~mL}^{-1}$ of the ready-to-drink Feel Good green tea, followed by $145 \mathrm{mg} .200 \mathrm{~mL}^{-1}$ of the infusion prepared with Leão tea bag. These results are important since the beneficial health effects of green tea are mostly connected with their antioxidants, mainly catechins. Therefore, it is important to inform the consumer that these levels may vary from product to product.

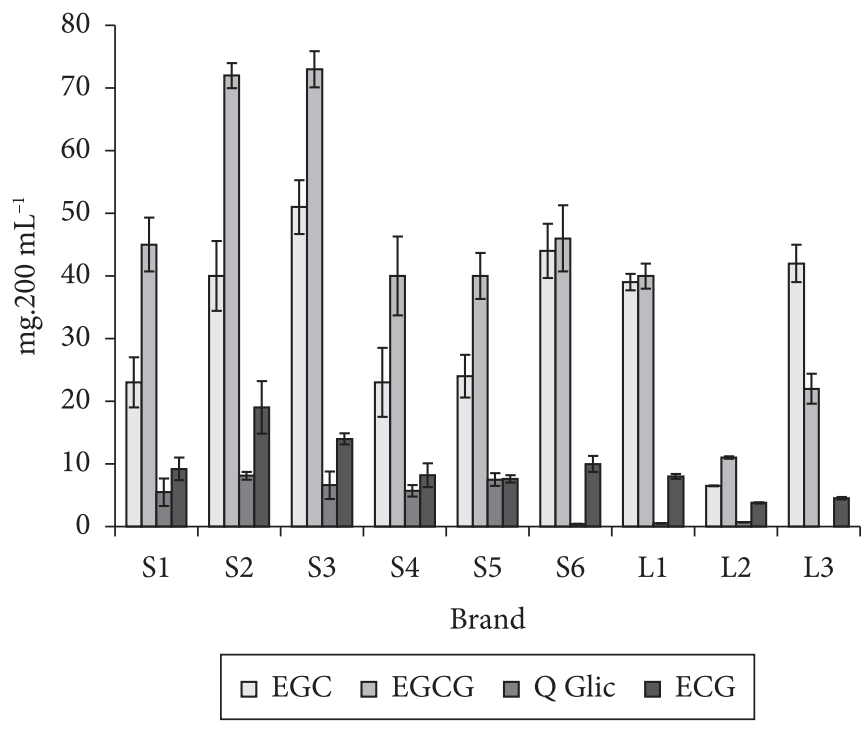

Figure 4. Flavonoid contents $\left(\mathrm{mg} .200 \mathrm{~mL}^{-1}\right)$ of different green tea preparations. Teas prepared from sachets (teabags): S1, Kitano (1.8 g), S2, Real Multiervas (1.5 g), S3, Leão (1.6 g), S4, Api-Chá (1.5 g), S5, Dr. Oetker (1.7 g) and S6, Yamamotoyama (2.0 g). Infusions prepared from green tea leaves $(1.5 \mathrm{~g})$ : L1, Yamamotoyama, L2, Banchá, L3, Senchá. EGC, epigallocatechin; ECG, epicatechin gallate; EGCG, epigallocatechin gallate; GC, gallocatechin; Q Glic, quercetin glycosydes.

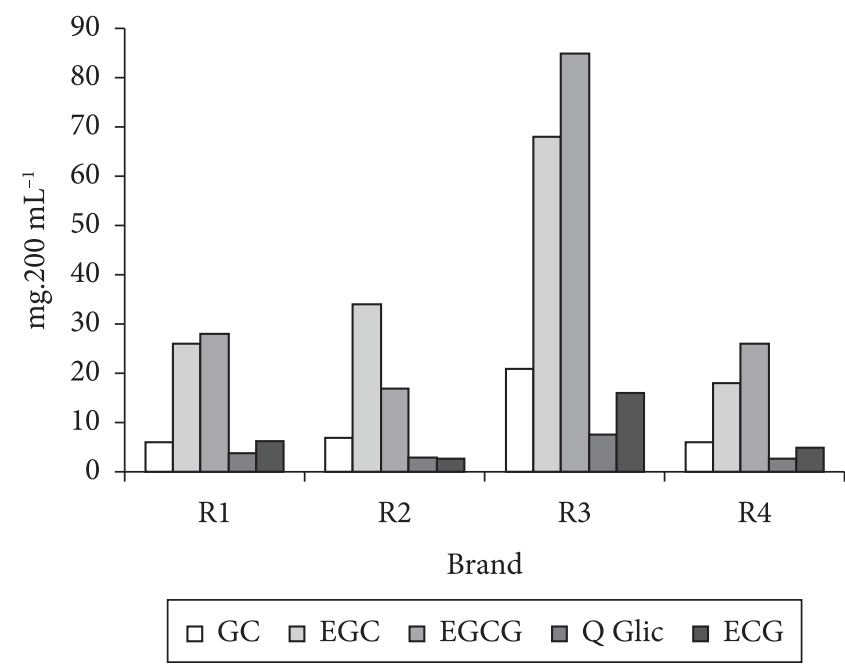

Figure 5. Flavonoid contents of ready-to-drink green tea beverages (mg.200 mL $\mathrm{m}^{-1}$ ). R1, Leão, R2, Feel Good with soy, R3, Feel Good, and R4, Lipton. EGC, epigallocatechin; ECG, epicatechin gallate; EGCG, epigallocatechin gallate; GC, gallocatechin; Q Glic, quercetin glycosydes.

\section{Conclusions}

There are no differences among infusions prepared from tea bags, dry leaves, or ready-to-drink commercial preparations in terms of the phenolic contents and in vitro antioxidant capacities. However, the antioxidant capacity of ready-to-drink products also results from the presence of other non-phenolic compounds such as ascorbic acid. 


\section{Acknowledgements}

The authors are grateful for the financial support provided by The National Council for Scientific and Technological Development $(\mathrm{CNPq})$, which granted a Scientific Initiation Scholarship (PIBIC/CNPq) to an undergraduate student (Débora Harumi Kodama).

\section{References}

ARABBI, P. R.; GENOVESE, M. I.; LAJOLO, F. M. Flavonoids in vegetable foods commuly consumed in Brazil end estimated by the brazilian population. Journal of Agricultural and Food Chemistry, v. 52, p. 1.124-1.131, 2004.

BRAND-WILLIANS, W.; CUVELIER, M. E.; BERSET, C. Use of free radical method to evaluate antioxidant activity. LebensmittelWissenschaft und-Technologie, v. 28, p. 25-30, 1995.

CHENG, Z.; MOORE, J.; YU, L. High-throughput relative DPPH radical scavenging capacity assay. Journal of Agricultural and Food Chemistry, v. 54, n. 20, p. 7429-7436, 2006.

DÁVALOS, A.; GÓMEZ-CORDOVÉS, C.; BARTOLOMÉ, B. Extending applicability of the oxygen radical absorbance (ORAC) assay. Journal of Agricultural and Food Chemistry, v. 52, p. 48-54, 2004.

DUARTE-ALMEIDA, J. M. et al. Avaliação da atividade antioxidante utilizando sistema $\beta$-caroteno/ácido linoléico e método de seqüestro de radicais DPPH. Ciência e Tecnologia de Alimentos, v. 26, n. 2, p. 446-452, 2006.

GENOVESE, M. I. et al. Bioactive compounds and antioxidant capacity of exotic fruits and commercial frozen pulps from Brazil. Food Science and Technology International, v. 14, n. 3, p. 207-214, 2008.

HASsimotTo, N. M. A.; GENOVESE, M. I.; LAJOlO, F. M. Antioxidant activity of dietary fruits, vegetables, and commercial frozen fruit pulps. Journal of Agricultural and Food Chemistry, v. 53, p. 2928-2935, 2005.

HENNING, S. M. et al. Catechin content of 18 teas and green tea extract supplement correlates with the antioxidant capacity. Nutrition and Cancer, v. 45, n. 2, p. 226-235, 2003.
HeRTOG, M. G. L.; HOLLMAM, P. C. H.; KATAN, M. B. Content of potentially anticarcinogenic flavonoids of tea infusion, wines and fruit juices. Journal of Agricultural and Food Chemistry, v. 41, p. 1242-1246, 1993.

HUANG, D.; OU, B.; PRIOR, R. L. The chemistry behind antioxidant capacity assays. Journal of Agricultural and Food Chemistry, v. 53, p. 1841-1856, 2005.

MATSUBARA, S.; RODRIGUEZ-AMAYA, D. B. Conteúdo de miricetina, quercetina e kaempferol em chás comercializados no Brasil. Ciência e Tecnologia de Alimentos, v. 26, n. 2, p. 380-385, 2006.

NAGLE, D.; FERREIRA, D.; ZHOU, Y. Epigallocatechin-3-gallate (EGCG): chemical and biomedical perspectives. Phytochemistry, v. 67, p. 1849-1855, 2006.

NIJVELDT, R. J. et al. Flavonoids: a review of probable mechanisms of action and potential applications. American Journal of Clinical Nutrition, v. 74, p. 418-425, 2001.

OU, B.; HAMPSCH-WOODILL, M.; PRIOR, R. L. Development and validation of an improved oxygen radical absorbance capacity assay using fluorescein as the fluorescent. Journal of Agricultural and Food Chemistry, v. 49, p. 4619-4629, 2001.

PRIOR, R. L.; CAO, G. Antioxidant capacity and polyphenolic components of teas: implications for altering in vivo antioxidant status. Proceedings of the Society for Experimental Biology and Medicine, v. 220, n. 4, p. 255-261, 1999.

SEERAN, N. P. et al. Catechin and caffeine content of green tea dietary supplements and correlation with antioxidant capacity. Journal of Agricultural and Food Chemistry, v. 54, p. 1599-1603, 2006.

SINGLETON, V. L.; ORTHOFER, R.; LAMUELA-RAVENTOS, R. M. Analysis of total phenols and other oxidation substrates and antioxidants by means of Folin-ciocalteu reagente. Methods of Enzymology, v. 299, p. 152-178, 1999.

WANG, H.; PROVAN, G. J.; HELLIWELL, K. Tea flavonoids: their functions, utilization and analysis. Trends in Food Science and Technology, v. 11, p. 152-160, 2000.

WU, C. D.; WEI, G. X. Tea as a functional food for oral health. Nutrition and Oral Health, v. 18, p. 443-444, 2002. 